NBER WORKING PAPER SERIES

\author{
HIGH-INCOME FAMILIES AND THE TAX \\ CHANGES OF THE 1980S: THE \\ ANATOMY OF BEHAVIORAL RESPONSE
}

Joel Slemrod

Working Paper No. 5218

\author{
NATIONAL BUREAU OF ECONOMIC RESEARCH \\ 1050 Massachusetts Avenue \\ Cambridge, MA 02138 \\ August 1995
}

Prepared for the NBER Conference on Tax Policy Analysis, held in Islamorada, Florida on January 19-21, 1995. Forthcoming in The Econometrics of Taxation, University of Chicago Press. I am grateful for able research assistance provided by Jon Bakija, Victoria Kilgore, and Hisahiro Naito, and for helpful comments on an earlier draft from James Alm, Don Fullerton, James Poterba and other participants at the NBER conference. This paper is part of NBER's research program in Public Economics. Any opinions expressed are those of the author and not those of the National Bureau of Economic Research.

(c) 1995 by Joel Slemrod. All rights reserved. Short sections of text, not to exceed two paragraphs, may be quoted without explicit permission provided that full credit, including $\odot$ notice, is given to the source. 


\title{
HIGH-INCOME FAMILIES AND THE TAX CHANGES OF THE 1980S: THE ANATOMY OF BEHAVIORAL RESPONSE
}

\begin{abstract}
The relative income gains of the affluent after the passage of the Tax Reform Act of 1986 (TRA86), which sharply lowered tax rates at high income levels, are overstated by comparing cross-sectional slices using concurrent income definitions, but they are large nevertheless. Although an index of the demand-side factors affecting inequality throughout the income distribution can explain much of the increased high-income concentration until 1985, it cannot adequately explain the post-TRA86 spurt. Thus, TRA86 is likely to have been a principal cause of the large increase in the reported personal income of the affluent. A close look at the sources of the post-1986 increases in the reported individual income of high-income households suggests that much of it represents shifting of income -- for example, from the corporate tax base to the individual tax base -- and not income creation such as additional labor supply. This distinction is critical because knowing how much the reported individual income of a particular group of people changes in response to a tax change is not a sufficient statistic for evaluating adequately its revenue consequences, incidence, and efficiency.
\end{abstract}

Joel Slemrod University of Michigan Business School

Room 2120D 701 Tappan Street Ann Arbor, MI 48109-1234 and NBER 
Joel Slemrod

\section{Introduction}

It is indisputable that many high-income individuals took notice of, and responded to, certain aspects of the tax changes enacted in the 1980s. Indeed, some of the behavioral responses are now the stuff of legend, such as the $96.3 \%$ increase in capital gains realizations in 1986 compared to 1985 , in anticipation of the tax increase on gains scheduled for 1987 .

Another striking bit of evidence is the enormous increase in the real income levels of high-income families during the 1980s, both in absolute terms and relative to the real income increases of everyone else. Between 1978 and 1990 the real increase in the reported income of the top $1 \%$ of tax returns, ranked by income, was $91.6 \%$; the real increase for everyone else rose was $18.9 \%$. Over this period, the shares of total income received by the top $1 \%$ of tax returns rose from $8.8 \%$ to $13.4 \%$.

In contrast to the capital gains episode, there is much controversy over the causal connection between the increased incomes of high-income families and the tax changes of the 1980s. There is a large literature ascribing the increased income inequality during the decade to technological change, particularly computerization, that increased the relative productivity of skilled labor, and a related literature associating the inequality to increased globalization of the U.S. economy. Even in the absence of any behavioral response at all, the increasing return to highly-skilled occupations would cause increasing absolute and relative incomes of the well-to-do.

One of the objectives of this paper is to separate out the non-tax and tax explanations of the increased income dispersion. I investigate this issue in Section 3 of the paper, where I report the results of some aggregate time-series regression analysis. I conclude that, although the non-tax demand factors can explain much of the increased 
concentration of income up to 1985 , they are unlikely to be the cause of the spike in concentration of reported incomes that began in 1986 .

The second objective of the paper is to characterize what behavioral response did occur by whether it was timing or likely to be permanent, and in particular whether it reflected income creation or income shifting. This characterization has important implications for the revenue, incidence, and efficiency of tax changes, and for the generalizability of the behavioral response of the tax changes of 1980s to future tax changes. This task is attempted in Section 4.

Before I get to these tasks, I first review, in Section 2, the existing literature on these issues.

\section{A Critical Review of Existing Literature}

The details of the two major tax bills of the 1980s have been carefully laid out elsewhere (cf. Steuerle (1992)), and need not be repeated here. In brief, the Economic Recovery Tax Act of 1981 (ERTA) lowered the top individual income tax rate from $70 \%$ to $50 \%$, and lowered all other tax rates in three annual steps by a total of about twentythree percent (not twenty-three percentage points). The reduction in the top rate overstates somewhat the decline in the effective marginal tax rate on labor income, because since 1970 the maximum tax on earned income had limited the marginal tax rate nominally to $50 \%$, and effectively to no more than a number in the mid-fifties for nearly all high-income workers.

The Tax Reform Act of 1986 (TRA86) contained scores of provisions, and cannot be adequately summarized in a sentence or two. Of direct concern to this paper is the reduction of the top rate of individual income tax from $50 \%$ to $28 \%$, in two steps from 1986 to 1988 . The exclusion of $60 \%$ of long-term capital gains was eliminated, so that the top effective rate on gains increased from $20 \%$ (40\% of $50 \%$ ) to $28 \%$ (100\% of $28 \%$ ). The basic corporate tax rate was lowered from $46 \%$ to $34 \%$. 
There have been innumerable studies of the impact on the federal tax changes enacted since 1981. In what follows I attempt only a selective review of some of the research which focused on the response of high-income taxpayers. Lindsey (1987) was among the first to point out that the 1981 cut in the top tax rate from $70 \%$ to $50 \%$ coincided with a very large increase in the share of income reported by the top $1 \%$ of the income distribution to the Internal Revenue Service. He argued that the tax cut was a principal cause of this income increase, as it reduced the penalty for earning (to be precise, reporting) taxable income.

Lindsey's methodology did not enable him to distinguish his tax causality hypothesis from an obvious alternative -- that, for non-tax reasons, pre-tax income inequality was growing rapidly between his two years of data, 1981 and 1985 . To be fair, this alternative hypothesis is more apparent in 1995 than it was at the time that Linds $-y$ was writing. In the past decade there has arisen i voluminous hilerature documenting an increase in inequality in the U.S., much of it summarized in Levy and Murnane (1992). As Karoly (1994) documents, data from the Census Bureau revealed that inequality among families, after reaching a post-war low in 1967-68, began to increase during the 1970s and continued to rise through the 1980s. Although the trend toward greater inequality began in the late 1960s, about two-thirds of the absolute increase in the Gini coefficient between 1968 and 1989 occurred between 1980 and 1989 . Although these basic facts are now widely acknowledged, the origin of the increase in inequality remains highly controversial. The two leading explanations, which are not mutually exclusive, are technological change that increased the relative return to skilled labor, and increased globalization of the U.S. economy, which increased the effective relative supply of unskilled labor and thereby lowered its relative return.

That inequality began to increase in 1970 does not rule out the tax causality hypothesis. As Feenberg and Poterba (1993) and Slemrod (1994a) point out, the top individual marginal tax rate has been monotonically declining since 1962. Moreover, the 
approximate starting time of the increase in inequality, 1970, coincides with the introduction of the maximum tax on earned income, which reduced the marginal tax rate on labor income to $50 \%$ (or slightly more), even though the top marginal tax rate on other income stayed at $70 \%$ until 1981 . Thus, there is an a priori case to be made that the tax causality hypothesis applies much more generally than the period Lindsey analyses -- at least since 1970 .

At this point a caveat is in order about the data commonly used to measure income inequality. The Current Population Survey (CPS) data analyzed by Karoly and others features top coding of income amounts at a constant (although occasionally increased) nominal level. For this reason it cannot measure reliably changes in, for example, the share of income earned by the top $1 \%$ of the distribution. Standard summary measures of income distributions, in addition to the Gini coefficient, are the income at the 10th, 25th, 50th, 75th, 90th, and 95th percentiles, but none higher than the 95 th percentile.

Thus, any conclusion about, say, the share of income earned by the top $1 \%$ of the population, must come from some other data source other than the CPS or, because it suffers from the same sort of problem, the Panel Study on Income Dynamics. Tax researchers have made use of the public-use files of tax return data released by the Statistics of Income (SOI) Division of the Internal Revenue Service. There is no topcoding problem with this data; in fact, high-income individuals are over-sampled in order to produce a very precise picture of their tax returns. The tax return data, though, have their own strengths and weaknesses. They contain virtually no demographic information -- marital status, state of residence, and whether the taxpayer or spouse is over 65 being notable exceptions -- and no information on labor supply or labor market status more generally. These data also exclude those households whose income is below the threshold for filing an income tax return. 
Summary measures of income inequality based on the tax data show the same patterns as more commonly used data -- continually increasing inequality since 1972 of all income, and also of wages and salaries by themselves. Feenberg and Poterba (1993) have recently used tax return data to calculate a time series of inequality measures that focuses on high-income households. Using interpolations of published SOI aggregated data, they calculate the share of adjusted gross income (AGI) and several components of AGI that were received by the top $0.5 \%$ of households arranged by income. Their plot of the high-income share of adjusted gross income is reproduced in the bold line in Figure 1. After being approximately flat at about $6.0 \%$ from 1970 to 1981 , it begins in 1982 to increase continuously to $7.7 \%$ in 1985 , and then jumps sharply in 1986 to $9.2 \%$. There is a slight increase in 1987 to $9.5 \%$, then another sharp increase in 1988 to $12.1 \%$. After 1988 there is a decline to $11.2 \%$ in 1989 and $10.9 \%$ in 1990.

Feenberg and Poterba also report that among tis top income earners, the largest increase in share is attributed to the top one-fifth of one percent. This fact, they assert, "casts doubt on the view that the factors responsible for the increase in reported incomes among high-income taxpayers, especially in the 1986-1988 period, are the same factors that were responsible for the widening of the wage distribution over a longer time period." (p. 161) Rather, they argue, "it reflect[s] other factors including a tax-induced change in the incentives that high-income households face for reporting taxable income." [p. 170, emphasis added] They add that with their data "it is impossible to determine how much of the increase in reported income was due to changes in tax avoidance behavior; how much was due to changes in real behavior such as labor supply; and how much was due to changing returns to the factors, labor and capital, that high-income taxpayers own." (p. 163) 
The Feenberg/Poterba calculations refer to the share of AGI received by the rich, despite the fact that the definition of AGI changed during this period. ${ }^{1}$ A change in the definition of AGI has two distinct effects on a share measure of income concentration. These two distinct effects are nicely illustrated using the most important set of changes in AGI definition over the period in question -- those pertaining to long-term capital gains. From 1970 to 1978 half of realized long-term capital gains were included in AGI. The Tax Reform Act of 1978 lowered the fraction included in AGI to forty percent for gains realized after October 31, 1978. The Tax Reform Act of 1986 eliminated the exclusion altogether, so that for gains realized as of January 1, 1987, all of realized long-term gains were included in adjusted gross income.

Consider the change in AGI definition made as of 1987. As long as income is measured by AGI, including $100 \%$ rather than $40 \%$ of capital gains in AGI increases the apparent concentration of income, becalise capital gains are heavily concentrated among high-income households. It also changes the ranking of taxpayers, pushing toward the top of the income distribution those households whose income consists of a relatively high share of capital gains. This reranking makes the apparent share of capital gains received by high-income households increase, and the share of other sources of income increase or decline depending on the cross-sectional correlation of that source with capital gains.

In order to investigate the empirical importance of these effects, I first recalculate the top income shares of AGI, wages and salaries, and capital gains in 1984 and 1990, using in each case both the 1984 and 1990 definitions of adjusted gross income. These results are shown in Table 1, calculated separately for the top $1 \%$ of households ranked by AGI, and (approximately) the top $0.5 \%$, the Feenberg-Poterba cutoff. Consider, as an example, the upper-right-hand panel of Table 1. It shows that the share of AGI received

${ }^{1}$ This is noted in footnote 5 of Feenberg and Poterba (1993). 
by the top $0.5 \%$ of income earners increased from $7.4 \%$ in 1984 to $10.8 \%$ in 1990 , using concurrent definitions of income. But a significant fraction of that $3.4 \%$ increase is an artifact of changing AGI definitions. When one uses a consistent 1990 definition of income to compare concentration, the $3.4 \%$ increase becomes a $1.9 \%$ increase; when one uses a consistent 1984 definition, the $3.4 \%$ increase falls to $2.7 \%$.

It is also insightful to compare measures of capital gains concentration using concurrent and consistent definitions of income, as is done in the bottom panels of Table 1. Consider the numbers based on the top $0.5 \%$ of income earners. Using a concurrent definition of income, one would conclude that the concentration of capital gains increased by $2.6 \%$, from $52.2 \%$ to $54.8 \%$. In contrast, using a consistent definition reveals that the concentration actually declined over this period by either $3.1 \%$ or $3.6 \%$, depending on which consistent definition of income is used.

Aggregate time-series data on shares should, for more accurate compal:bility, be evaluated with a consistent definition. As a first step toward that task, Figures 1 and 2 present the Feenberg-Poterba time series on AGI and capital gains, from 1970 to 1990, and, using dotted lines, how the post-1986 figures would be adjusted to reflect the definition of income from 1978 to 1986; the adjustments in 1987, 1988, and 1989 are assumed to be proportionately the same as in 1990 .

Adjusting the data in this way does not change the impression that the measured concentration of AGI increased sharply between 1981 and 1990; the magnitude of the increase is, though, smaller than what one would estimate using concurrent income definitions. Using consistent income definitions also clarifies the temporary upward blip of the concentration of capital gains in 1986, due to extraordinary capital gains realizations in anticipation of the tax increase scheduled for 1987. With a consistent definition, the 1986 blip becomes much more apparent, and the post-1986 era is characterized by a concentration that is no higher than the 1982-1985 period. 
I have argued for the importance of using consistent income definitions when doing cross-year comparisons of the distribution of income and income components. However, even when consistent income definitions are employed, there are important conceptual problems with comparing cross-sectional slices of income distributions, because one is comparing different groups of households across years.

The potential problem due to rank reversals can be illustrated by an extreme example. Imagine if all of these taxpayers in the top $1 \%$ of the income distribution in 1990 were, in 1984, below the $1 \%$ cutoff and in 1984 had marginal tax rates below $28 \%$; furthermore, as follows from the above, all of the households in the top $1 \%$ in 1984 , who had tax rates of $50 \%$, were below the top $1 \%$ cutoff in 1990 , with tax rates of $28 \%$ or lower. In this case it would certainly not be valid to conclude, from observing that the top $1 \%$ in 1990 received a larger share of total income than did the top $1 \%$ in 1984 , that the reduction $\therefore$ - the top tax rate "caused taxpayers to report more inc. mu." In this hypothetical example those households that experienced the largest increase in income had an increase in their tax rate.

There is, in fact, considerable year-to-year movement within the top income class. Slemrod (1992) reports that in the 1980s, between 28 and 40 percent of the households in the top $1 \%$ were new from one year to the next. Another reason to be wary of comparing cross-sections of high-income households is that, in a critical dimension, this group is bimodal. In particular, as Slemrod (1994a) discusses, the distribution of the ratio of urges and salaries to total income is bimodal, with local maxima at $0-10 \%$ and 90 $100 \%$, and a minimum at $50-60 \%$. This reflects the fact that the affluent consist of both retired households, whose income is almost entirely the returns from their accumulated wealth, and well-compensated people in their working years.

There is some intriguing evidence that the set of high-income taxpayers in 1990 in fact has a very different demographic makeup than the set in 1984. According to tax return data, the fraction of taxpaying units containing at least one person aged 65 or over 
fell dramatically over this period, from $22.4 \%$ to $14.1 \%$ for the top $0.5 \%$ of the population, and from $20.5 \%$ to $13.4 \%$ for the top $1 \%$; over the same period for all taxpayers the fraction rose only very slightly, from $12.0 \%$ to $12.1 \% .^{2}$ The same demographic pattern is observed in comparing the 1983 and 1989 data from the Survey of Consumer Finances. Apparently in the highest income group the retired, couponclipping rentiers were to a large extent displaced by high-earning people between 1984 and 1990. Thus, the reasons to be cautious about comparing cross-sectional slices are not only hypothetical, but are quantitatively significant.

The potential hazards of inferring behavioral response from comparing the behavior of two distinct groups of taxpayers can be mitigated by analyzing longitudinal, or panel, data on an unchanging set of taxpayers. This has been done in the work of Feldstein (1993) and Auten and Carroll (1994).

I.cldstein (1993) investigates the high-income respo:se to tie Tax Reform Act of 1986 by making use of the Ernst \& Young/University of Michigan tax return panel data. This panel, based on SOI tax return data, follows the same set of taxpayers from 1979 to 1988. Feldstein analyzed married couples for whom both 1985 and 1988 tax returns were available. After making several adjustments to the data, he concludes that the 1985-1988 percentage increase in various measures of income, particularly taxable income excluding capital gains, was much higher, compared to the rest of the population, for those high-income groups whose marginal tax rate was reduced the most. Based on this finding, he estimates that the elasticity of taxable income with respect to the marginal tax rate is very high, and suggests that an increase in the top marginal tax rate will raise little, if any, revenue.

A few caveats must be attached to this finding. First, because the panel data is not stratified, it contains only a very small number of high-income observations. For

\footnotetext{
${ }^{2}$ The ranking of households is based on a 1984 definition of AGI.
} 
example, the top income class on which Feldstein focuses most of his attention (nonelderly couples in the 49 to 50 percent tax brackets in 1985) contains only 57 observations. Because of the wide variation among this group in financial situation and in income changes over time, generalizing from such a small sample is problematic.

This difficulty is illustrated by taking a closer look at the exercise reported in Feldstein. The most striking result is a 71.6 percent increase in the taxable income of those in the top income class between 1985 and 1988, after subtracting out capital gains and indexing for per-capita personal income growth. Of the total increase in this measure of income, nearly three-quarters was accounted for by an increase in two sources of income which are reported on Schedule E -- partnerships and S corporations. One taxpayer, whose $\mathrm{S}$ corporation income increased from about $\$ 5,000$ in 1985 to over $\$ 3$ million by 1988 , was responsible for 47.5 percent of this growth in net partnership and $\mathrm{S}$ corporation income. Just four taxpayers acu, inted for 87.0 percent of the increase. As the analysis of stratified cross-sectional data in Section 4 will make clear, changes in $\mathrm{S}$ corporation and partnership income were in fact probably an important part of the income gains of the affluent, although they did not dominate to the extent that this panel data, dominated by a single observation, would suggest.

The importance of $\mathrm{S}$ corporation and partnership income in Feldstein's results also suggests caution regarding the interpretation that lower marginal tax rates induced the rich to engage in more real income-producing activities. The tremendous growth in $\mathrm{S}$ corporation income may simply represent a shift from $\mathrm{C}$ to $\mathrm{S}$ status among corporations, rather than the creation of new income that would not otherwise have been taxed. ${ }^{3}$

\footnotetext{
${ }^{3}$ As discussed in detail later, the Tax Reform Act of 1986 reduced the top individual tax rate below the top corporate rate, repealed the "General Utilities doctrine" (which increased the tax burden on sales of C corporation assets), and instituted a tough alternative minimum tax for $\mathrm{C}$ corporations. This made $\mathrm{S}$ corporations (which are subject only to the individual income tax) more attractive than $\mathrm{C}$ corporations (which face the corporate profits tax) for many small business owners. Thus, a large increase in $S$ corporation income after 1986 probably represents a shifting of taxable income from the corporate to individual tax systems, rather than growth of companies that already held $S$ status before 1986 . Feldstein attempted to avoid this problem by excluding from his sample all taxpayers who reported $\mathrm{S}$ corporation
} 
Moreover, as Feldstein notes, some of the large reduction in partnership losses was probably due to new passive-loss limitation rules rather than the reduction in rates. Other non-marginal-rate factors, such as elimination or limitation of some types of itemized deductions, also contributed to the growth in taxable income among the rich.

Auten and Carroll (1994) make use of a much larger longitudinal data set, consisting of 14,102 tax returns for the same set of taxpayers for 1985 and 1989. The sample observations are stratified, so that high-income taxpayers are over-sampled. Thus, there are 4,387 taxpayers in the $49 \%$ or $50 \%$ tax rate bracket in 1985 ; this compares to 57 in Feldstein's panel. They regress the change in AGI between 1984 and 1989 against the change in marginal tax rate and, in some specifications, some demographic variables. They also control for occupation, as a proxy for demand-side, non-tax factors that affected the change in compensation over this period. They conclude that changes in tax rates appear to ie an imporiant determinant of the income growth of the late 1980s, although the results are somewhat sensitive to the choice of sample and weighting. They caution, as I will later in the paper, that their results do not necessarily indicate that tax-induced income growth yielded a proportional rise in total tax revenues; due to the potential for shifting of income, that depends on the source of the income change.

\section{Aggregate Time-Series Analysis of Trends in Income Inequality}

Many have suggested that the changes in the pattern of income tax rates was a key causal factor behind the data shown in Figures 1 and 2; they argue that the increased concentration reflects a larger behavioral response of high-income individuals due to the

income in 1988 but not in 1985 . However, the one taxpayer remaining in the sample who accounted for almost all of the growth in $S$ corporation income had only a nominal amount of $S$ corporation income in 1985 and over $\$ 3$ million in 1988. Although this may represent an incredible success story for a small $S$ corporation of which the taxpayer was a shareholder in 1985 , it is also possible that this taxpayer was also a shareholder of at least one already-large $C$ corporation that switched to $S$ status between 1985 and 1988. In any event, it is difficult to make generalizations about high-income taxpayers from the behavior of any one household. 
larger drop in their marginal tax rates. There is, though, a competing non-tax explanation for the trend of increased concentration of income that began about 1970 but accelerated about 1980 -- a change in the structure of wage rates, due to an increase in the premium on education. Between 1979 and 1988 there was a 15 percent increase in the average wage of a college graduate relative to that of a high school graduate; the high-school/elementary-school wage differential also increased substantially. A large literature in labor economics has documented the increasing inequality in pre-tax earnings, and has debated the underlying causes of this phenomenon; analysis of the tax changes over this period has been conspicuously absent from this debate. Instead the debate has centered around technological changes which favor skilled over unskilled labor, the increased integration into the world economy of countries with abundant unskilled labor, and changes in the U.S. supply of skilled versus unskilled workers.

Virtually all of the er: $i_{1}$ irical research on trends in inequality has been based ois data that does not include the high-income households that are the subject of this paper. Yet it is arguable that the same factors which have caused the increasing dispersion of income in the lower 99 percentiles are also relevant to the relative earnings of the highincome households in the top percentile. For this reason it is important in an empirical analysis of the effect of taxes to control for the exogenous non-tax factors that have been affecting the distribution of income.

In what follows I describe a series of multivariate regression analyses of the timeseries evidence on high-income shares of income and sources of income. The objective of this exercise is to identify the permanent and temporary impact of changes in the tax 
structure and anticipated changes in that structure, holding constant some non-tax influences. ${ }^{4}$ By separately performing the regressions for the years up to 1986 and for the years up to 1990, I also investigate whether there was a change in the structure of the model in 1986.

The dependent variables for the regressions are the shares of AGI and four sources of income -- wages and salaries, interest, dividends, and capital gains ${ }^{5}$-- received by the top $0.5 \%$ of households for 1954 through 1990 . The data up to 1986 are taken directly from Feenberg and Poterba (1993). The data from 1987 through 1990 are based on Feenberg and Poterba's, but are adjusted to correspond to a pre-TRA86 definition of adjusted gross income, for reasons described in Section $2 .{ }^{6}$

Given the small number of observations in this analysis, a critical challenge is to identify the best, small, set of tax variables that captures the important aspects of a given year's tax envir.ument. Because the focus of this inquiry is the behavic. of the highincome group relative to the rest of the population, I construct a measure of the difference between a weighted-average marginal tax rate on labor income for the top $0.5 \%$ of taxpayers and the weighted-average marginal rate on all other tax return filers, using AGI as the weighting factor. This is denoted TL. ${ }^{7}$

Included as regressors are the current rate, the expected one-year-ahead change (measured by the actual change), and the change from the previous year. The maximum

\footnotetext{
${ }^{4}$ These regressions should be interpreted as the reduced form of a structural model in which the own inequality of each income source depends on the dispersion in how it is taxed and, via rank reversals, in which each income source's concentration as ranked by income depends on all other source's inequality and the shares of each source in total income. Thus the right-hand side of each reduced-form equation ought to contain the set of all right-hand variables in the structural equations.

5 Unfortunately, the data does not permit an analysis over this period of the concentration of business income.

${ }^{6}$ The adjustment is carried out as follows. The 1990 tax return data are sorted by the pre-TRA86 definition of adjusted income, and the high-income shares are re-calculated. The Feenberg-Poterba shares for 1987,1988 , and 1989 are then multiplied by the ratio of the ratio of recalculated 1990 share to the Feenberg-Poterba 1990 share. This procedure is carried out separately for each of the five shares.

${ }^{7}$ The construction of TL and the other variables are described in more detail in a data appendix available from the author.
} 
marginal tax rate on long-term capital gains (denoted TC) is also included, although not compared to the average rate ${ }^{8}$ this is also entered in concurrent, expected change, and lagged change form. The standard corporation income tax rate is not included as an explanatory variable, on the grounds that over this period it changed substantially only once, by virtue of TRA86; for this reason this variable would likely pick up much of the explanatory power of all of the TRA86-induced changes. I return to this issue below.

As discussed above, many economists accept that there were economic forces, unrelated to the tax system, which over this period caused increased inequality in the return to labor. The issue at hand is how to statistically control for these factors. One approach would be to include measures of the alleged causes of the earnings dispersion; for example, technological change could be proxied by the extent of computerization, globalization by the import share of GNP, and the cohort effect by the fraction of


problem by using as a control a measure of the dispersion of earnings in the population as a whole. Specifically, I use the difference between the logarithm of the 90 th percentile and the logarithm of the 10th percentile of male weekly wages (denoted WGINEQ), based on Census data, as reported in Katz and Murphy (1992), updated past 1987 using data reported by Karoly (1993), and extended before 1963 using data from Goldin and Margo (1992). Because this index is not affected by changes in the share of wages going to the very affluent, it is not endogenous. It does, however, arguably reflect the same economic forces that would affect the return to the labor of the most affluent.

As additional explanatory variables I include the real level of stock prices (RSTPR), to pick up its impact on capital gains realization behavior, and the average nominal corporate AAA bond rate (AAARATE), to account for its influence on the

\footnotetext{
${ }^{8}$ For 1954 to 1978 , the rate is taken from the first row in Table 1.13 of U.S. Department of Treasury (1985). This measure takes into account the provisions that would commonly affect very high income taxpayers, including the alternative minimum tax and temporary surcharges in 1968, 1969, and 1970. For years after 1978, the top rate is taken from annual Statistics of Income publications.
} 
receipt of taxable interest. I experimented with the prime-age male unemployment rate as a business cycle indicator, but it was not an important factor and is not included in the regressions reported here.

The results of the regression analyses are presented in Table 2 . In discussing them, I will refer to the effect of the concurrent tax rate as the permanent effect, and to the effect of the expected future and lagged tax changes as timing effects. Several tentative conclusions can be drawn from Table 2. One striking one is the large impact of capital gains tax on the share of capital gains of the affluent. Using either the series ending in 1985 or 1990 , the results suggest that an 8 percentage point increase in the top capital gains tax rate (the increase due to TRA86) would permanently lower the highincome share of capital gains by about 9 or 10 percentage points; if the increase were to be expected in advance, a 6 percentage point increase in the high-income share would uscur the year before the increase went into ef:-ict. The sltimate impact of the capital gains effect on the high-income share of adjusted gross income is, however, dampened substantially; it moves only about a tenth as much as the capital gains share itself.

I turn now to the core issue of the relative importance of tax effects and demandside effects on the increase in inequality. Consider the determinants of the high-income share of total wages and salaries. According to the regression analyses, the relative contribution of the demand-side effect, represented by WGINEQ, and the permanent tax effect, represent by $\mathrm{TL}_{t}$, depends entirely on the weight placed on the experience of 1986 through 1990. Based on the regression for the period 1954 to 1985, the demand-side effect dominates. For example, of the 1.3 percentage point increase in the high-income share of wages between 1973 and 1985, 0.53 can be associated with the increase in WGINEQ (a 0.22 increase in WGINEQ multiplied by the estimated coefficient of 2.406), and only 0.26 can be associated with $\mathrm{TL}_{t}$ (a 9.8 decline in $\mathrm{TL}_{\mathrm{t}}$ multiplied by an estimated coefficient of -0.0266). However, the regression using data through 1990 tells a 
completely different story. ${ }^{9}$ Based on this regression, one would conclude that almost the entire increase in the high-income share of wages can be associated with the decline in $\mathrm{TL}_{t}$, leaving no role for WGINEQ. A similar story can be told about the high-income share of AGI, although in this case the wage inequality variable is not as successful in explaining the pre-TRA86 variation..$^{10}$

The proximate cause for the divergence in results is clear. The 1985 to 1990 increase in the high-income share of wages exceeded the increase over the entire period of 1973 to 1985. Yet over this period the measure of demand-side effects, the difference between the log of earnings at the 90 th percentile and 10th percentile, actually fell after rising continuously for two decades, while the tax rate measure continued its downward trend, having its steepest decline of any comparable period.

These findings are open to two, not mutually exclusive, interpretations. One interpretation is that there was a fundame.. al break in the nature of the demand-side factor, so that up until 1985 its impact on the relative return to high-income occupations was well proxied by the changes in the overall distribution of earnings, but that after 1985 the relative return to the $99.5 \%$ percentile and above continued to increase even though the relative return to the 90 th percentile did not. A second possible interpretation is that the observed changes in high-income shares between 1986 and 1990 were primarily tax-driven but, except for the capital gains response, were of a fundamentally different nature and/or magnitude than what had been observed until 1986.

Although I cannot rule out the first explanation, I do not explore it further in this paper. Instead, in the following section I take a closer look at the high-income behavioral response to TRA86, with the goal of learning more about its nature.

\footnotetext{
${ }^{9}$ A Chow predictive test (Fisher, 1970) rejects the null hypotheses that the set of coefficients is the same in the pre- and post-TRA86 periods.

${ }^{10}$ Note, though, that many of the coefficient estimates shown in Table 2 are sensitive to the inclusion of the variable AAARATE; the qualitative conclusions discussed here are not.
} 


\section{A Closer Look at the Income Gains of the Affluent: Income Creation vs. Income Shifting}

Table 3 allows a closer look at the composition of the high-income real income increases in the late 1980 s by comparing the top $1.0 \%$ and $0.5 \%$ of income earners in 1984 and 1990. The right-hand panel reveals that the total increase in real reported income among the top $0.5 \%$ of taxpayers (in 1990 dollars) from 1984 to 1990 was $\$ 137.5$ billion. Three sources accounted for $76.8 \%$ of the total increase. Wages and salaries accounted for $\$ 57.0$ billion, or $41.5 \%$ of the total income. Small business corporation income (Subchapter S corporations) accounted for $\$ 27.2$ billion, or $19.8 \%$ of the total increase. Partnership income accounted for $\$ 21.3$ billion, or $15.3 \%$ of the total increase.

Auten and Carroll (1994) report, using their panel data set, that of the total change in nominal AGI of their highest income group (those subject to the $49 \%$ or $50 \%$ rate in 1985), only $29.1 \%$ was accounted for by the increase in wages and salaries. Mort than that was due to the combination of Subchapter S corporation income, which by itself was $25.1 \%$ of the increase, and partnership income, which accounted for $12.1 \%$ of increase. Strikingly, they report that the real wages and salaries of the highest income group increased by only $4.9 \%$ between 1985 and 1989 , compared to $161.8 \%$ for income from Subchapter S corporations, and $351.4 \%$ for income from partnerships. ${ }^{11}$ Because both the comparative cross-sectional and panel data indicate that the same three sources of income dominated the income gains of the rich over this period, I devote the rest of this section to further analysis of their trends.

\subsection{Subchapter S Income}

There are clear tax reasons for the $\$ 27.2$ billion increase in the reported income of the affluent from Subchapter $S$ corporations. The top individual income tax rate was cut

\footnotetext{
"Note that, because they group taxpayers by their marginal tax rate in 1985 , the subsequent income growth is subject to downward bias due to the presence of transitory income and regression toward the mean.
} 
by 22 percentage points, compared to a 12 point cut in the corporation income tax rate. By 1988 the top individual income tax rate was actually lower than the corporate tax rate for the first time since the introduction of the federal income tax. Because $\mathrm{S}$ corporations are not subject to corporation income tax, and are taxed essentially as partnerships, the tax penalty for high-income owners from operating as a corporation widened substantially upon the passage of TRA86.

There is substantial evidence of a large shift in activity from $C$ corporations to $S$ corporations. For one thing, the number of corporations filing to obtain $\mathrm{S}$ status ${ }^{12}$ increased dramatically at the time of enactment. In the first six months of 1987 , there were 375,000 filings, compared to a six-month change of 150,000 from 1983 to 1986 .

Figure 3 shows that the relative number of $\mathrm{C}$ and $\mathrm{S}$ corporation returns has changed dramatically since 1986 . The number of $\mathrm{C}$ returns, which had increased at an average rate of $3 .: \%$ in the two decades from 1965 to 1985 , actually startec to decrease after 1986, and fell by over 450,000 from 1986 to 1990 . At the same time S corporation returns more than doubled from 1985 to 1990 . S corporation returns, which represented $19 \%$ of all corporation returns in 1981 and $22 \%$ by 1985 , had surged to $42 \%$ of all returns by 1990 . The share of total corporate assets in $S$ form has also nearly doubled since the early 1980 s although it is still only slightly above $4 \% .^{13}$

As Nelson (1993) reports, much of the increase in S corporation activity was undertaken by high-income individuals. Whereas in 1985, 56 percent of the positive income went to taxpayers with income over $\$ 200,000$, in 1990 the figure was 71 percent. In 1985, of this group 23.9 percent had some S corporation income or loss; in 1990 this percentage had risen to 31.7 .

\footnotetext{
${ }^{12}$ These filings could be either new corporations or C corporations changing status. Nelson (1993) reports that in $1989,69.5$ percent of the assets of new $S$ corporations were held by "conversions," defined as a firm electing $S$ status more than one year after its date of incorporation.

13 See Gordon and MacKie-Mason (1994) for an empirical analysis of how tax factors have affected the relative size of the corporate and noncorporate business sectors.
} 
Of most direct interest is the change in where net income is reported. The net income of S corporations has increased sharply since TRA86, from $\$ 8.3$ billion in 1986 to $\$ 32.3$ billion in 1990 .

Non-rate-related tax changes may also have contributed to the shift from $C$ to $S$ corporations. In particular, the TRA86 repeal of the "General Utilities doctrine", which allowed corporations to avoid two levels of capital gains tax on asset sales, made C corporations a relatively less attractive organizational form. The expanded alternative minimum tax on corporations also had such an effect.

\section{$4.2 \quad \underline{\text { Partnerships }}$}

The TRA86 reversal of the relative position of the top corporate and individual marginal tax rates also increased the attractiveness of partnerships (and sole proprietorships) relative to Subchapter C corporations. As in the case of S corporations, though, a potentially important non-rate-related change occurred -- the passive loss limitations. These limitations disallowed, under certain conditions, individual taxpayers' deductions from taxable income of business losses defined as originating in "passive activities" (where the individual does not materially participate in the active conduct of the trade or business on a regular, continuous, or material basis). Pre-TRA86, most passive losses were allocated to the partners in limited partnerships. The limitations were phased in, beginning in 1987 and ending in $1991 .^{14}$

As Petska and Wilson (1994) document, the total number of partnerships, which had increased by $23 \%$ between 1980 and 1986, started to decline markedly in 1987, and by 1990 was $9 \%$ lower than in 1986. Aggregate net income of partnerships averaged $-\$ 7.1$ billion between 1981 and 1986 , but had risen to $+\$ 16.6$ billion by 1990 .

\footnotetext{
14 See Samwick (1995) for an attempt to empirically identify how much of the change in reported partnership income is due to the change in tax rates, and how much is due to the passive loss limitation rules.
} 


\subsection{Wages and Salaries}

The comparative cross-sectional evidence, but to a much lesser extent the panel data, suggest that increased wages and salaries are an important part of the high-income behavioral response. Part of the cross-sectional story is undoubtedly that the demographic makeup of the rich changed significantly from 1984 to 1990. This demographic change is reflected by the sharp drop in the fraction of rich households who are over 65 , from $23.4 \%$ to $14.1 \%$ for the top $0.5 \%$ of taxpayers. The mere fact that less of the rich are likely to be retired in 1990 will account for some amount of increased wages and salaries. There is also likely to be a rank reversal effect in which, as net partnership and Subchapter S income surges, it brings into the top income group more people who also have relatively high wages and salaries.

The preceding are cautions about inferring real behavioral changes from comparing cross-sectional slices of an income distriblito. Leaving this issue aside, the key question is how much of the observed relative increase in labor income is explained by increased relative pre-tax rates of compensation, increased labor supply, or by some sort of income shifting.

The first explanation cannot be ruled out. However, as discussed in Section 3, if this occurred, it occurred in the face of a decline in the dispersion of earnings between the 10th and 90th percentile of earners.

Eissa (1994) presents evidence, based on comparing cross-section slices of the pre- and post-TRA86 Current Population Surveys, that the labor supply of those married women facing sharp marginal tax declines due to TRA86 did in fact increase their labor supply relative to other married women. The labor income of married women, though, comprises a small fraction of the total labor income of the top $1 \%$ of households. Moreover, the labor supply literature speaks clearly that this is the group whose labor supply responsiveness is larger than that of any other, so that one cannot generalize from their behavior about the labor supply behavior of all members of affluent households. 
More definitive statements about the magnitude of labor supply response will have to await future research.

Another intriguing, and unsolved, question is the extent to which the increase in the wages and salaries of the rich is itself a reflection of income shifting. For example, the TRA86 reduction in the top rate of tax on ordinary income made it relatively less attractive to receive compensation in the form of untaxed fringe benefits and relatively more attractive to receive taxed monetary compensation. The elimination of the tax rate differential between ordinary income and long-term capital gains eliminated the incentive to repackage labor income into capital gains, including the incentive to receive stock options as part of one's compensation package. These are examples of changes in the form of one's labor income payments that would show up in concurrent tax return data as an increase in labor income. More generally, the inversion of the top corporate and


corporation, so that one would expect that post-TRA86 there would be an increase in payments from the corporations to individuals, payments that reflect neither a change in labor supply nor in the present value of labor compensation. The fact that the increase in the reported labor income of affluent individuals has been paralleled by a secular decrease in reported corporate profits is casual evidence for this income shifting hypothesis, but there is as of yet no evidence making the causal link anything more than speculative.

\section{$4.4 \quad$ Implications for the Regression Analyses}

The preceding discussions makes clear that much of the post-TRA86 increase in the income reported by high-income households on their personal tax returns was probably not due to a standard (e.g., increased labor supply) behavioral response to lower marginal tax rates. Instead there was a great deal of income shifting and changed reporting due to unique aspects of TRA86 that did not accompany previous marginal tax 
rate changes and are not likely to accompany future changes. According to this argument, the sharp divergence in the regression results when the post-TRA86 era is included occurs because there was indeed a new (tax) structure instituted then, one that provided very different incentives and opportunities for high-income individuals to report income (and losses) via the individual income tax system. The results do not imply that taxpayer response to marginal tax rates, holding structure constant, was different (in particular, higher) post-TRA86. Instead the tax rate variables, which changed dramatically at the same time the structure changed, are picking up some of the effect of the structural change. ${ }^{15}$

An intriguing question is why, given that many of the structural changes in TRA86 concerned business income, there is a break at 1986 in the equation explaining the high-income share of wages and salaries. One possible answer is that there is a positive cross-household cGi:-lation between the share of total income that is nict business income and the share that is wages and salaries. Given this correlation, any exogenous increase in the concentration of reported business income will, by pulling more households with business income into the top $0.5 \%$, also increase the concentration of wages and salaries. The other answer is that there were aspects of TRA86 that affected the incentive to report labor compensation as wages and salaries, as discussed in Section 4.3. It is unlikely that these two explanations are the whole story, implying that this paper has not completely explained the surge in the concentration of wages and salaries after TRA86.

\section{Conclusions}

The relative income gains of the affluent after the passage of TRA86 are overstated by comparing cross-sectional slices using concurrent income definitions, but they are large nevertheless. Although an index of the demand-side factors affecting

\footnotetext{
15 I am grateful to the discussant of this paper, Don Fullerton, for clarifying this argument for me.
} 
they are large nevertheless. Although an index of the demand-side factors affecting inequality throughout the income distribution can explain much of the increased highincome concentration until 1985, it cannot adequately explain the post-TRA86 spurt. TRA86 is likely to have been a principal cause of the large increase in the reported personal income of the affluent. A close look at the sources of the post-1986 increases in the reported individual income of high-income households suggests that much of it represents shifting of income -- for example, from the corporate tax base to the individual tax base -- and not income creation such as additional labor supply.

This distinction is critical because knowing how much the reported individual income of a particular group of people changes in response to a tax change is not a sufficient statistic for evaluating adequately the revenue consequences. This is because the change in reported personal income may be accompanied by offsetting changes in other tax bases, $\therefore$ particular the corporation income tax, and by offsettir..$_{c}$ changes in reported income in other time periods. Thus, the extent to which changes in reported income are indications of the shifting of income across tax bases or time periods needs to be carefully studied.

The nature of the behavioral response is also critical for evaluating the incidence and efficiency of taxation. In Slemrod (1994b) I argue that the standard tools for measuring these concepts must be modified in the presence of what I call "avoidance," defined as responses to taxation other than altering one's consumption bundle, including income shifting. 
Joel Slemrod

\section{$\underline{\text { References }}$}

Auten, Gerald and Robert Carroll, "Behavior of the Affluent and the 1986 Tax Reform Act: The Role of Demand-Side Characteristics," unpublished paper, U.S. Treasury Dept., November 1994.

Eissa, Nada, "Taxation and the Labor Supply of Married Women: The Tax Reform Act of 1986 as a Natural Experiment," unpublished paper, Harvard University, November 1993.

Feenberg, Daniel and James Poterba, "Income Inequality and the Incomes of Very High Income Taxpayers," in J. Poterba, ed., Tax Policy and the Economy, Volume 7 (Cambridge, MA: The MIT Press, 1993).

Feldsteir, M `tin, "The Effect of Marginal Tax Rates on Taxable Ihcom``A Panel Study of the 1986 Tax Reform Act," NBER Working Paper No. 4496, October 1993.

Fisher, Frank, "Tests of Equality Between Two Sets of Coefficients in Two Linear Regressions: An Expository Note," Econometrica, 28, 1970, pp. 361-366.

Goldin, Claudia and Robert A. Margo, "The Great Compression: The Wage Structure in the United States at Mid-Century, " Quarterly Joumal of Economics, (February 1992), pp. 1-34.

Gordon, Roger and Jeffrey MacKie-Mason, "How Much Do Taxes Discourage Incorporation?" Unpublished Paper, University of Michigan, 1994.

Karoly, Lynn, "The Trend in Income Inequality Among Families, Individuals, and Workers in the United States: A Twenty-Five Year Perspective," in S. Danziger and P. Gottschalk, eds., Uneven Tides: Rising Inequality in America (New York: Russell Sage Foundation, 1993). Also data updates obtained from the author. 
Karoly, Lynn, "Trends in Income Inequality: The Impact of, and Implications for, Tax Policy," in J. Slemrod, ed., Tax Progressivity and Income Inequality, (Cambridge, UK: Cambridge University Press, 1994).

Katz, Lawrence F., and Kevin M. Murphy, "Changes in Relative Wages, 1963-1987:

Supply and Demand Factors," Quarterly Journal of Economics, (February 1992), pp. 35-78.

Levy, Frank and Richard S. Murnane, "U.S. Earnings Levels and Earnings Inequality: A Review of Recent Trends and Proposed Explanations," Journal of Economic Literature, (September 1992), pp. 1333-81.

Lindsey, Lawrence, "Estimating the Behavioral Responses of Taxpayers to Changes in Tax Rates: 1982-1984. With Implications for the Revenue-Maximizing Tax Rate," Journal of Public Economics (July 1987), pp. 173-206.

Nelson, Susan C., "S Corporations: The Record of Grov. h After Tax Reform," Journal of S Corporation Taxation (Fall 1993), pp. 138-161.

Petska, Thomas and Robert Wilson, "Trends in Business Structure and Activity, 19801990," Statistics of Income Bulletin, (Spring 1994), pp. 27-72.

Samwick, Andrew A.,. "Tax Shelters and Passive Losses After the Tax Reform Act of $1986, "$ this volume.

Slemrod, Joel, "Taxation and Inequality: A Time-Exposure Perspective," in J. Poterba, ed., Tax Policy and the Economy, volume 6, (Cambridge, MA: The MIT Press, 1992).

Slemrod, Joel, "On the High Income Laffer Curve," in J. Slemrod, ed., Tax Progressivity and Income Inequality. (Cambridge, U.K.: Cambridge University Press, 1994a). Slemrod, Joel, "A General Model of the Behavioral Response to Taxation," Unpublished paper, University of Michigan, September 1994b. 
Steuerle, C. Eugene, The Tax Decade: How Taxes Came to Dominate the Public Agenda. (Washington, D.C.: Urban Institute Press, 1992).

U.S. Department of Treasury, Office of Tax Analysis, Report to the Congress on the Capital Gains Tax Reductions of 1978, (Washington, D.C.: Superintendent of Documents, 1985). 
Table 1

High-Income Shares of Income, Wages and Salaries and Capital Gains Using Concurrent and Consistent AGI Definitions

Top 1\%

Adjusted Gross Income

\begin{tabular}{|rcc|}
\hline \multicolumn{2}{r}{1984 definition } & 1990 definition \\
1984 data & 9.9 & 11.5 \\
1990 data & 13.4 & 14.2 \\
\hline
\end{tabular}

Wages and Salaries

1984 definition

1990 definition

1984 data

6.5

6.2

2.6

1990 data

\section{Top 0.5\%}

Adjusted Gross Income

1984 definition

1990 definition

1984 data $\quad 7.4$

8.9

1990 data 10.1

10.8

\begin{tabular}{|c|c|c|c|c|c|}
\hline \multicolumn{3}{|c|}{ Wages and Salaries } & \multicolumn{3}{|c|}{ Wages and Salaries } \\
\hline \multicolumn{2}{|c|}{1984 definition } & 1990 definition & \multicolumn{2}{|c|}{1984 definition } & 1990 definition \\
\hline 1984 data & 6.5 & 6.2 & 1984 data & 4.5 & 4.2 \\
\hline 1990 data & 8.7 & $? .6$ & 1990 data & 6.1 & 6.0 \\
\hline \multicolumn{3}{|c|}{ Capital Gains } & \multicolumn{3}{|c|}{ Capital Gains } \\
\hline \multicolumn{2}{|c|}{1984 definition } & 1990 definition & \multicolumn{2}{|c|}{1984 definition } & 1990 definition \\
\hline 1984 data & 58.1 & 65.6 & 1984 data & 52.2 & 58.4 \\
\hline 1990 data & 56.2 & 62.7 & 1990 data & 49.1 & 54.8 \\
\hline
\end{tabular}

Source: Author's tabulations using 1984 and 1990 Individual Income Tax Model data from the Statistics of Income Division of the Internal Revenue Service. Not all the relevant changes in the definition of adjusted gross income were, or could be, accounted for. In converting 1984 data to the 1990 definition, the following items were accounted for: dividends exclusion, excluded long-term capital gains, moving expenses, employee business expenses, and the two-earner deduction in unemployment benefits included in AGI, and gross unemployment benefits. In converting the 1990 data to the 1984 definition, the following were accounted for: capital gains, dividend exclusion under 1984 law, unemployment compensation, self-employment tax deduction, self-employed health insurance deduction, unreimbursed employee business expense deduction, and moving expense deduction. 
Table 2

Time-Series Regression Analyses of the High-Income Shares of

AGI, Wages and Salaries, Capital Gains, Interest and Dividends, 1954-85 and 1954-90

AGI

Wages and Salaries
Capital Gains

Interest

Dividends

\begin{tabular}{|c|c|c|c|c|c|c|c|c|c|c|}
\hline \multirow[b]{2}{*}{$\begin{array}{c}\text { Independent } \\
\text { Variables }\end{array}$} & 1954-85 & $1954-90$ & 1954-85 & $1954-90$ & 1954-85 & $1954-90$ & 1954-85 & $1954-90$ & $1954-85$ & $1954-90$ \\
\hline & \multirow[b]{2}{*}{$\begin{array}{r}-0.00565 \\
(0.0471)\end{array}$} & \multirow[b]{2}{*}{$\begin{array}{c}-0.190^{*} \\
(0.0253)\end{array}$} & \multirow[b]{2}{*}{$\begin{array}{c}-0.0266 \\
(0.0179)\end{array}$} & \multirow[b]{2}{*}{$\begin{array}{c}-0.126^{*} \\
(0.0111)\end{array}$} & \multirow[b]{2}{*}{$\begin{array}{c}0.484 \\
(0.393)\end{array}$} & \multirow[b]{2}{*}{$\begin{array}{c}-0.277 \\
(0.148)\end{array}$} & \multirow[b]{2}{*}{$\begin{array}{c}0.312 \\
(0.180)\end{array}$} & \multirow[b]{2}{*}{$\begin{array}{c}-0.459^{*} \\
(0.0832)\end{array}$} & \multirow[b]{2}{*}{$\begin{array}{l}0.433^{*} \\
(0.219)\end{array}$} & \multirow[b]{2}{*}{$\begin{array}{c}0.124 \\
(0.0915)\end{array}$} \\
\hline $\mathrm{TL}_{\mathrm{t}}$ & & & & & & & & & & \\
\hline$T L_{t+1}-T L_{t}$ & $\begin{array}{c}0.0502 \\
(0.0445)\end{array}$ & $\begin{array}{c}-0.0672 \\
(0.0356)\end{array}$ & $\begin{array}{c}0.0213 \\
(0.0170)\end{array}$ & $\begin{array}{c}-0.0571^{*} \\
(0.0156)\end{array}$ & $\begin{array}{c}0.54) \\
(0.373)\end{array}$ & $\begin{array}{c}0.281 \\
(0.209)\end{array}$ & $\begin{array}{c}0.182 \\
(0.170)\end{array}$ & $\begin{array}{l}-0.263^{*} \\
(0.117)\end{array}$ & $\begin{array}{c}0.205 \\
(0.207)\end{array}$ & $\begin{array}{c}0.207 \\
(0.129)\end{array}$ \\
\hline $\mathrm{TL}_{\mathrm{t}}-\mathrm{TL}_{\mathrm{t}-1}$ & $\begin{array}{c}0.0491 \\
(0.0254)\end{array}$ & $\begin{array}{c}0.0434 \\
(0.0338))\end{array}$ & $\begin{array}{c}0.0303^{*} \\
(0.0112)\end{array}$ & $\begin{array}{c}0.0267 \\
(0.0148)\end{array}$ & $\begin{array}{l}-0.2 \div 1 \\
(0.246)\end{array}$ & $\begin{array}{c}-0.134 \\
(0.198)\end{array}$ & $\begin{array}{l}0.0193 \\
(0.112)\end{array}$ & $\begin{array}{c}0.148 \\
(0.111)\end{array}$ & $\begin{array}{c}-0.318 * \\
(0.137)\end{array}$ & $\begin{array}{l}-0.174 \\
(0.122)\end{array}$ \\
\hline $\mathrm{TC}_{\mathrm{t}}$ & $\begin{array}{c}-0.108^{*} \\
(0.0139)\end{array}$ & $\begin{array}{c}-0.0806^{*} \\
(0.0196)\end{array}$ & $\begin{array}{c}-0.0154^{*} \\
(0.00529)\end{array}$ & $\begin{array}{c}-0.00385 \\
(0.00862)\end{array}$ & $\begin{array}{l}-1.20^{*} \\
(0.116)\end{array}$ & $\begin{array}{l}-1.10^{*} \\
(0.115)\end{array}$ & $\begin{array}{l}-0.265^{*} \\
(0.0531)\end{array}$ & $\begin{array}{c}-0.182^{*} \\
(0.0645)\end{array}$ & $\begin{array}{c}-0.193 * \\
(0.064)\end{array}$ & $\begin{array}{c}-0.139 \\
(0.0710)\end{array}$ \\
\hline $\mathrm{TC}_{\mathrm{t}+1}-\mathrm{TC}_{\mathrm{t}}$ & $\begin{array}{l}0.0294^{*} \\
(0.0328)\end{array}$ & $\begin{array}{c}0.0450 \\
(0.0423)\end{array}$ & $\begin{array}{c}-0.0195 \\
(0.0124)\end{array}$ & $\begin{array}{r}-0.0280 \\
(0.0186)\end{array}$ & $\begin{array}{l}0.859^{*} \\
(0.274)\end{array}$ & $\begin{array}{l}0.823 * \\
(0.248)\end{array}$ & $\begin{array}{c}0.224 \\
(0.125)\end{array}$ & $\begin{array}{c}0.126 \\
(0.139)\end{array}$ & $\begin{array}{r}-0.0725 \\
(0.153)\end{array}$ & $\begin{array}{l}0.0968 \\
(0.153)\end{array}$ \\
\hline$T C_{t}-T C_{t-1}$ & $\begin{array}{c}0.0813 \\
(0.0409)\end{array}$ & $\begin{array}{c}0.0500 \\
(0.0459)\end{array}$ & $\begin{array}{r}-0.00988 \\
(0.0156)\end{array}$ & $\begin{array}{l}0.00582 \\
(0.0202)\end{array}$ & $\begin{array}{c}0.516 \\
(0.342)\end{array}$ & $\begin{array}{c}0.239 \\
(0.269)\end{array}$ & $\begin{array}{c}0.258 \\
(0.156)\end{array}$ & $\begin{array}{c}0.245 \\
(0.151)\end{array}$ & $\begin{array}{c}0.00562 \\
(0.190)\end{array}$ & $\begin{array}{l}-0.297 \\
(0.166)\end{array}$ \\
\hline RSTPR & $\begin{array}{c}-0.00705^{*} \\
(0.00232)\end{array}$ & $\begin{array}{c}-0.0109^{*} \\
(0.00317)\end{array}$ & $\begin{array}{c}-0.00683^{*} \\
(0.000884)\end{array}$ & $\begin{array}{c}-0.00900^{*} \\
(0.00139)\end{array}$ & $\begin{array}{c}0.0416^{*} \\
(0.0194)\end{array}$ & $\begin{array}{c}0.0306 \\
(0.0186)\end{array}$ & $\begin{array}{c}-0.0463^{*} \\
(0.00888)\end{array}$ & $\begin{array}{c}-0.0596 * \\
(0.104)\end{array}$ & $\begin{array}{r}-0.00575 \\
(0.0108)\end{array}$ & $\begin{array}{c}-0.0109 \\
(0.0115)\end{array}$ \\
\hline AAARATE & $\begin{array}{c}-0.0895 \\
(0.0537)\end{array}$ & $\begin{array}{c}-0.291^{*} \\
(0.0585)\end{array}$ & $\begin{array}{c}0.0227 \\
(0.0205)\end{array}$ & $\begin{array}{c}-0.0584^{*} \\
(0.0257)\end{array}$ & $\begin{array}{c}0.424 \\
(0.449)\end{array}$ & $\begin{array}{c}-0.217 \\
(0.343)\end{array}$ & $\begin{array}{c}-0.149 \\
(0.205)\end{array}$ & $\begin{array}{l}-0.704 * \\
(0.193)\end{array}$ & $\begin{array}{c}-0.774^{*} \\
(0.250)\end{array}$ & $\begin{array}{l}-1.20 \\
(2.12)\end{array}$ \\
\hline Intercept & $\begin{array}{c}10.2^{*} \\
(4.39)\end{array}$ & $\begin{array}{l}21.5 * \\
(4.14)\end{array}$ & $\begin{array}{c}2.19 \\
(1.67)\end{array}$ & $\begin{array}{l}9.47^{*} \\
(1.82)\end{array}$ & $\begin{array}{c}32.9 \\
(36.7)\end{array}$ & $\begin{array}{l}86.5^{*} \\
(24.3)\end{array}$ & $\begin{array}{c}18.0 \\
(16.8)\end{array}$ & $\begin{array}{l}76.1^{*} \\
(13.6)\end{array}$ & $\begin{array}{l}58.2^{*} \\
(20.5)\end{array}$ & $\begin{array}{l}-12.5 \\
(15.0)\end{array}$ \\
\hline $\mathrm{R}^{2}$ & 0.829 & 0.902 & 0.965 & 0.969 & 0.87', & 0.870 & 0.876 & 0.780 & 0.958 & 0.950 \\
\hline $\begin{array}{l}\text { Durbin- } \\
\text { Watson }\end{array}$ & 1.612 & 1.458 & 1.739 & 1.519 & 1.194 & 1.242 & 0.949 & 0.876 & 1.659 & 2.033 \\
\hline
\end{tabular}

*denotes significance at $95 \%$ level of confidence. Standard errors in parentheses. 
Table 3

Reported Personal Income of High-Income Taxpayers, 1984 and 1990 (1990 dollars)

\begin{tabular}{|c|c|c|c|c|c|c|c|c|}
\hline & \multicolumn{4}{|c|}{ Top 1\% } & \multicolumn{4}{|c|}{ Top $0.5 \%$} \\
\hline & 1984 & 1990 & Increase & $\begin{array}{c}\% \text { of Total } \\
\text { Incr ?ase }\end{array}$ & 1984 & 1990 & Increase & $\begin{array}{l}\% \text { of Total } \\
\text { Increase }\end{array}$ \\
\hline AGI & 265.6 & 445.9 & 180.2 & 10.0 & 198.4 & 335.8 & 137.5 & 100.0 \\
\hline Wages and Salaries & 145.9 & 226.9 & 80.9 & 44.9 & 101.6 & 158.6 & 57.0 & 41.5 \\
\hline Dividends & 20.8 & 27.1 & 6.3 & 3.5 & 16.9 & 22.3 & 5.4 & 3.9 \\
\hline Interest & 28.1 & 44.3 & 16.2 & 9.0 & 21.1 & 35.5 & 14.4 & 10.4 \\
\hline Business Income & 14.6 & 31.4 & 16.8 & 9.3 & 9.0 & 20.3 & 11.2 & 8.2 \\
\hline Capital Gains & 39.8 & 26.5 & -13.3 & -7.4 & 35.7 & 23.2 & -12.6 & 9.1 \\
\hline Partnership & -0.5 & 26.2 & 26.7 & 14.8 & -1.2 & 20.1 & 21.3 & 15.5 \\
\hline $\begin{array}{l}\text { S Corporation } \\
\text { Income }\end{array}$ & 10.3 & 40.0 & 29.7 & 16.5 & 9.6 & 36.9 & 27.2 & 19.8 \\
\hline
\end{tabular}

Source: Author's tabulations using 1984 and 1990 Individual Income Tax Model data from the Statistics of Income Division of the Internal Revenue Service. The ranking of households and definitions of income are based on the 1984 definition of adjusted gross income. Discrepancies among the 1984, 1990, and "Increase" columns are due to rounding error. 
Figure 1 -- Share of AGI received by top 0.5 percent of taxpayers, adjusted for consistency with 1984 definition of $A G I$

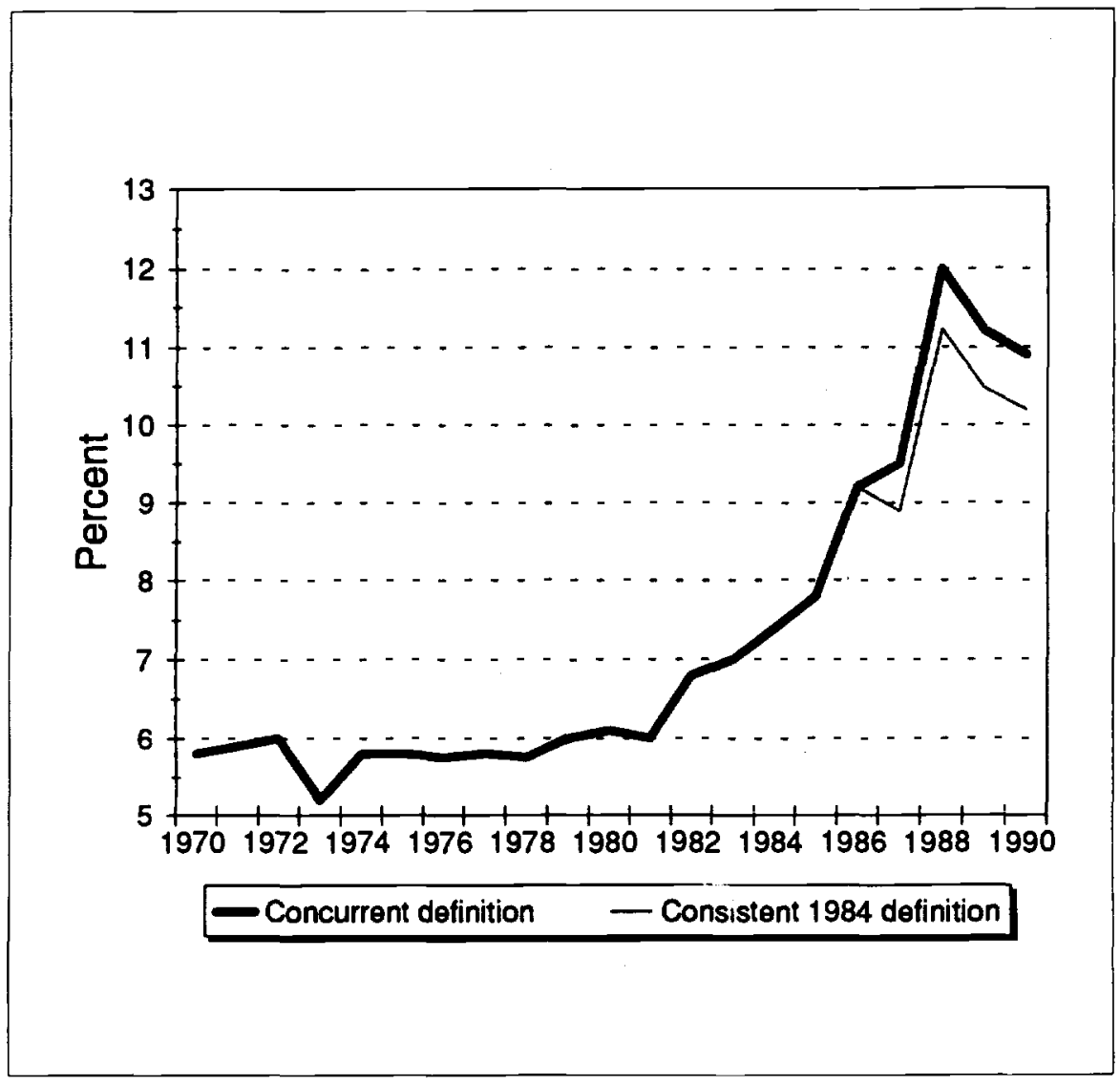

Source: Feenberg and Poterba (1993) and author's calculations based on 1990 IRS individual model file. 
Figure 2 -- Share of capital gains received by top 0.5 percent of taxpayers, adjusted for consistency with 1984 definition of AGI

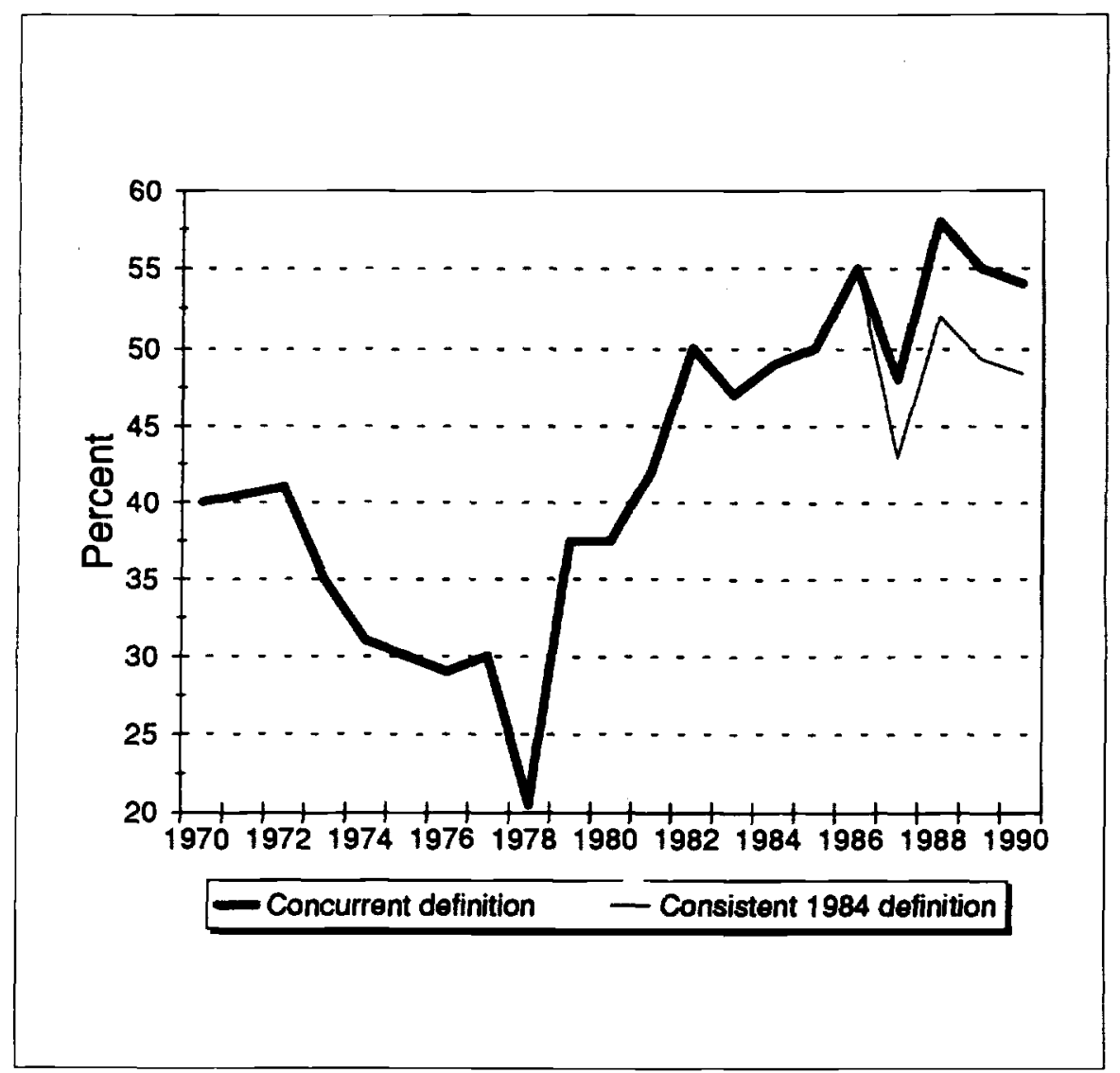

Source: Feenberg and Poterba (1993) and author's calculations based on 1990 IRS individual model file. 
Figure 3 -- Returns of $\mathrm{C}$ and $\mathrm{S}$ Corporations



Source: IRS Statistics of Income; Corporation Income Tax Retums 